\title{
Urdimento
}

Revista de Estudos em Artes Cênicas

E-ISSN: 2358.6958

\section{Espacialidades inquietas: SobreVivo, trajetórias de uma criação enegrecida}

Patricia Fagundes

Sandino Rafael Rosa

\section{Para citar este artigo:}

FAGUNDES, Patrícia; ROSA, Sandino Rafael. Espacialidades inquietas: SobreVivo, trajetórias de uma criação enegrecida. Urdimento, Florianópolis, v. 2, n. 38, ago./set. 2020.

DOI: http:/dx.doi.org/10.5965/14145731023820200008

Este artigo passou pelo Plagiarism Detection Software | iThenticate 
Espacialidades inquietas: SobreVivo, trajetórias de uma criação enegrecida`

Patricia Fagundes ${ }^{2}$

Sandino Rafael Rosa ${ }^{3}$

\title{
Resumo
}

O artigo reflete sobre o processo de criação de SobreVivo - Antes que o baile acabe, a partir das dinâmicas de composição espacial da montagem, considerando seus aspectos estéticos, éticos, poéticos, políticos e sociais. O espetáculo desenvolve temáticas étnico-raciais em uma abordagem antirracista que busca construir um espaço enegrecido da cena, tendo como referenciais manifestações culturais do povo negro, como funk, slam, samba e religiosidades de matriz africana, assim como noções afrocentradas, como a escrevivência e o quilombismo. A dramaturgia foi desenvolvida colaborativamente pela equipe, por meio de narrativas biográficas que evocam suas experiências em relação à negritude e ao racismo. Compõe-se uma cena simultaneamente crítica e festiva, que questiona as localizações sociais dos próprios espectadores.

Palavras-chave: Teatro. Antirracismo. Negritude. Festividade. Espacialidades.

Restless spatialities: SobreVivo, trajectories of a blackened creation

\begin{abstract}
The paper reflects on the creative process of SobreVivo - Antes que 0 baile acabe, focusing on the dynamics of the spatial composition of the performance, considering its aesthetic, ethical, poetic, political and social aspects. The play addresses ethnical-racial themes through an anti-racist approach that seeks to build a blackened space, supported by black people cultural manifestations, such as funk, slam, samba and African-based religiosity, as well as African-centered notions, such as escrevivência and quilombism. The dramaturgy was devised by the group through biographical narratives evoking their experiences in terms of blackness and racism. The scene conceived is both critical and festive, questioning the social positions of the viewers.
\end{abstract}

Keywords: Theater. Anti-racism. Blackness. Festivity. Spatialities.

\footnotetext{
${ }^{1}$ Este artigo está vinculado a dissertação de mestrado de Sandino Rafael Rosa. SobreVivo: Trajetórias de uma encenação enegrecida. Orientada por Patrícia Fagundes, e defendida em 2019, no Programa de PósGraduação em Artes Cênicas, da Universidade Federal do Rio Grande do Sul.

2 Profa. Dra. Universidade Federal do Rio Grande do Sul (UFRGS) no Departamento de Arte Dramática e no Programa de Pós-Graduação em Artes Cênicas (PPGAC). Encenadora. patfag26@hotmail.com

Mestre pelo Programa de Pós- Graduação em Artes Cênicas da UFRGS. Encenador. Educador. sandinorafael@gmail.com
} 
O teatro é algo que se faz entre pessoas, em certo espaço e tempo, uma ação organizada esteticamente que envolve gente reunida ou um tempo-espaço compartilhado de mortalidade. Podemos considerar que o teatro é feito de tempo, espaço e corpos, articulados mediante ações, jogos, conceitos. Esta definição pode também servir para pensar a cidade, lugar onde a sociedade se organiza, espaço de convívio e disputa, de encontro e exclusão. Ao pensar o tempo-espaço como eixo definidor do teatro e de nossa própria organização social, destacamos a importância discursiva da espacialidade na criação cênica, que materializa no agora da cena questões políticas, sociais, poéticas e est(é)ticas - toda estética carrega uma ética, um modo de posicionar-se diante do outro, de construir-se em relação social e compartilhamento do mundo. A partir desse horizonte, este trabalho propõe uma reflexão sobre questões relativas às espacialidades de um processo específico de criação cênica, entendida como microterritório de sociabilidade, considerando cruzamentos e pontos de intersecção/fricção entre teatro e cidade, espaço e memória, corpo e lugar, universidade e sociedade, arte e política, em uma perspectiva poética e estética que se propõe enegrecida e antirracista.

SobreVivo - Antes que o baile acabe é um espetáculo teatral que aborda temáticas étnico-raciais, desenvolvido nos anos de 2018 e 2019 como parte de pesquisa de mestrado no Programa de Pós-Graduação em Artes Cênicas (PPGAC) e também como Estágio de Atuação do Curso de Teatro da Universidade Federal do Rio Grande do Sul (UFRGS). Os autores do presente artigo acompanharam o processo de ensaios e apresentações nos papéis de diretor e orientadora, lugares que permitiram movimentos alternados de aproximação e distanciamento do processo artístico investigado, de autoria compartilhada entre toda a equipe criativa ${ }^{4}$. A equipe reúne um grupo de estudantes negros cotistas de graduação e pós-graduação, parte de uma geração universitária que está produzindo outros discursos e possibilidades críticas, relacionados ao que a artista e docente negra Celina Alcântara denomina como "fala negra":

${ }^{4}$ Atuação: Cira Dias, Esly Ramão, Gabriel Farias, Letícia Guimarães, Maya Marqz e Phillipe Coutinho. Direção: Sandino Rafael. Luz: Silvana Rodrigues. Orientação: Celina Alcântara e Patricia Fagundes. 
... uma fala negra de alunos e alunas negros e negras, que adentram em maior quantidade os portais da universidade hoje, o que torna possível um reconhecer-se em outros corpos como o seu; uma fala negra de alunos e alunas não negros, que muito comumente estranham as suas posições num lugar e num tempo em que não são considerados do ponto de vista étnico racial nem negros, nem brancos e daqueles e daquelas que se identificam como brancos, que, se, por um lado, gozam de um lugar de privilégio num ambiente social racista, estão cada vez mais sendo questionados e confrontados por esses privilégios. [...]. Quando penso numa fala negra, refiro-me a uma experiência de imbricamento, uma melange de corpos vozes e daquilo que eles dizem/praticam/pensam. [...]. Esses múltiplos sentidos emergem em várias medidas no momento do trabalho: na polifonia de sonoridades, de ideias, de corpos que se instaura na prática dos exercícios, no confronto consigo mesmo e com os outros da cena. (Alcântara, 2018, p. 293).

O sistema de cotas, implementado por meio de uma política de ações afirmativas, favoreceu a ampliação e o aprofundamento do debate étnico-racial na universidade brasileira, além da articulação de discursos de enfrentamento ao racismo, produzidos por uma geração de jovens negros que colocam experiências e realidades diversas em foco e debate. Nesse processo de ingresso e formação de novos pensadores, destaca-se o florescimento de produções pautando temáticas raciais em cursos de teatro e dança.

Esse florescimento é parte de um significativo movimento da cena brasileira contemporânea, que se posiciona em um território político de criação, no qual se destacam diversos artistas e coletivos negros que abordam questões raciais como discurso cênico central. Espetáculos como Qual a diferença entre o charme e o funk? (2014), do grupo Pretagô ${ }^{5}$, de Porto Alegre, Preto (2017), da Cia Brasileira de Teatro ${ }^{6}$, Isso é um negro? ${ }^{7}$ (2018), desenvolvido por estudantes negros do curso de Teatro da USP, Subterrâneo (2018), da companhia de dança paulistana Gumboot ${ }^{8}$, Exu, a boca do universo (2014), do Grupo de Teatro de Alagoinhas ${ }^{9}$, Eles não usam

\footnotetext{
${ }^{5}$ Página do grupo no Facebook: https://www.facebook.com/grupopretago/

${ }^{6}$ Site da companhia: http://www.companhiabrasileira.art.br/

7 Disponível em: https://mitsp.org/2019/isto-e-um-negro/. Acesso em: 27 ago. 2019.

${ }^{8}$ Rede social do grupo: https://www.facebook.com/gumbootdancebrasil/

${ }^{9}$ Rede social do grupo: https://www.facebook.com/NataTeatroAfrobrasileiro/
} 
tênis Nike (2015), da Cia. Marginal'10 do Rio de Janeiro, ou A missão em fragmentos: 12 cenas de descolonização em Legítima Defesa ${ }^{11}$, do coletivo Legítima Defesa, são alguns exemplos de uma produção recente e pulsante que questiona opressões étnico-raciais em diálogos críticos com a sociedade, propondo outros imaginários além da cultura hegemônica, que é definida por parâmetros da branquitude. Ainda que não possamos esquecer que a cena negra brasileira tem uma longa história, reconhecemos uma reverberação especial de discursos étnico-raciais na cena atual, em consonância com a urgente pauta nacional que questiona o racismo estrutural de uma nação constituída a partir do marco da exclusão racial, fundamentando uma sociedade pelos e para os sujeitos brancos. O mítico ideário brasileiro da democracia racial só reforça essa perspectiva, como já analisava o importante artista e intelectual negro Abdias do Nascimento (1978, p. 46):

Desde os primeiros tempos da vida nacional aos dias de hoje, o privilégio de decidir tem permanecido unicamente nas mãos dos propagadores e beneficiários do mito da "democracia racial". Uma "democracia" cuja artificiosidade se expõe para quem quiser ver; só um dos elementos que a constituíram detém o poder em todos os níveis político-econômicosociais: o branco. Os brancos controlam os meios de disseminar informações; o aparelho educacional; eles formulam conceitos, as armas, os valores do país. Não está patente que neste exclusivismo se radica o domínio quase absoluto desfrutado por algo tão falso quanto essa espécie de "democracia racial?"

$\mathrm{Na}$ tentativa de provocar fissuras neste "domínio quase absoluto", posicionam-se diversos movimentos antirracistas, assim como processos de enegrecimento nos últimos anos: enegrecer a universidade, os meios de comunicação, a História, a cultura apropriada, o teatro, o corpo, o cotidiano, a arte, a própria vida. Enegrecer como modo de subversão ao projeto colonial de embranquecimento da sociedade brasileira, que impôs a suposta inferioridade das pessoas e da cultura negra em relação a um modelo branco e eurocêntrico, idealizado como superior. Em seu fundamental estudo sobre os desafios da

10 Site Redes da Maré com informações sobre o grupo: https://redesdamare.org.br/br/info/1/cia-marginal

${ }^{11}$ A performance ocorreu durante a programação da 4ạ Mostra Internacional de Teatro de São Paulo (Mit-SP) em 2017. 
afirmação da identidade negra no Brasil, a intelectual negra Neusa dos Santos Souza (1983, p. 77) discorre sobre o processo de "tornar-se negro":

Ser negro é, além disto, tomar consciência do processo ideológico que, através de um discurso mítico acerca de si, engendra uma estrutura de desconhecimento que aprisiona numa imagem alienada, na qual se reconhece. Ser negro é tomar posse desta consciência e criar uma nova consciência que reassegure o respeito às diferenças e que reafirme uma dignidade alheia a qualquer nível de exploração. Assim ser negro não é um condição dada, a priori. É um vir a ser. Ser negro é tornar-se negro.

Tal perspectiva ressoa no pensamento da feminista negra Lélia Gonzalez, ao afirmar, em 1988, que "a gente não nasce negro, a gente se torna negro", e assim "uma pessoa negra que tem consciência de sua negritude está na luta contra o racismo" (Gonzalez apud Barreto, 2019, p.1). Está também presente na demanda por enegrecer o feminismo, articulada por Sueli Carneiro (2003), intelectual e feminista negra referencial no país, e no brado de diversos movimentos da juventude negra ${ }^{12}$. Enegrecer, uma palavra que ainda é definida em dicionários em sentido negativo (difamar, "denegrir"), foi assumida pelo ativismo negro antirracista como ato político que afirma e celebra a negritude, “desembranquecendo" um país que certamente não é branco. Enegrecer para que outros modos de existir possam vicejar. Em um momento de SobreVivo, o ator Cira Dias compartilha sua própria experiência de enegrecimento:

Eu sempre vivi rodeado de pessoas como vocês. Eu respirava, comia, dormia, falava, agia e até reproduzia os seus pensamentos racistas. Mas eu nunca fui um de vocês, eu sabia e todos vocês também sabiam, me chamavam de moreno "não você não é negro..." e eu sorria, aceitava o lugar onde me colocavam, ficava feliz por ter a pele clara o suficiente para não ser chamado de preto. Eu gostava da ideia de ser apenas moreno, nem branco, nem preto, moreno... Porém isso durava pouco tempo, passava a ser negro em um estalar de dedos [...]. Ajeite sua postura! Deixe a mochila à mostra! Neste instante você está entrando em uma loja! "EU NÃO SOU LADRÃO"! Mas dizem que a minha pele diz o contrário. (Dias apud Rosa, 2019, p. 123).

Histórias e narrativas biográficas como esta, que evocam relações de racismo,

${ }^{12}$ Ver, por exemplo, o Coletivo Nacional de Juventude Negra Enegrecer. https://www.facebook.com/Enegrecer/ 
negritude e branquitude, são um componente fundamental da dramaturgia de SobreVivo e também um dos recursos para afirmar o espetáculo como espaço de enegrecimento. Outros recursos somam-se a essa ação, como: equipe composta majoritariamente por artistas negros; desenvolvimento de referenciais culturais do povo negro, como o hip-hop, o samba, o funk, a religiosidade de matriz africana, o slam; questionamento político explícito das desigualdades e violências sociais. A própria pesquisa de mestrado que engendrou SobreVivo enegreceu-se em sua trajetória, já que inicialmente não estava centrada na questão étnico-racial, e sim em diálogos entre criação artística e política, de modo menos específico.

No começo do processo de criação cênica, a intenção era compor a partir da e para a rua, o que definiu a realização de um ciclo experimental de intervenções cênicas semanais no Centro de Porto Alegre (região onde está situado o prédio que abriga o Departamento de Arte Dramática - DAD - e a Pós-graduação em Artes Cênicas da UFRGS). No fluxo dessas intervenções, a participação dos estudantes em uma manifestação política específica foi importante na trajetória enegrecida da montagem: o ato pela memória da vereadora Marielle Franco e do motorista Anderson Gomes, assassinados a tiros em 14 de março de 2018 no Rio de Janeiro.

No dia 15 de março, diversas manifestações de luto e luta aconteceram em todo o Brasil. Em Porto Alegre, o ato ${ }^{13}$ foi na Esquina Democrática, espaço tradicional de manifestações políticas. Em um limiar entre ato político e ritual fúnebre, fazia-se um momento de reflexão e protesto pelo assassinato de Marielle, mulher negra, LGBT e da periferia que, em sua história de resistência e combate à violência policial, se tornou referência nacional. Em dado momento, a organização, composta principalmente pelo conjunto dos movimentos negros organizados de Porto Alegre, solicitou que jovens negros ocupassem o espaço de protagonismo na frente do carro de som e convocou as pessoas brancas a assumirem o entorno do ato, como um cordão humano, posto que o aparato policial que acompanha

${ }^{13}$ G1 RS. Marielle e Anderson são lembrados em ato em Porto Alegre, um dia após mortes. Disponível em: https://g1.globo.com/rs/rio-grande-do-sul/noticia/marielle-e-anderson-sao-lembrados-em-ato-em-portoalegre-um-dia-apos-mortes.ghtm. Acesso em: 17 mar. 2018. 
manifestações, com demasiada frequência, representa mais risco do que segurança à juventude negra. Na ocasião, um grito foi entoado pela lalorixá Sandrali Bueno $^{14}$ às pessoas brancas ali presentes: "sejam nossos escudos!"15. Vários estudantes do DAD, incluindo membros presentes e futuros da equipe de SobreVivo, participaram desse momento, quando se inverteu a lógica de protagonismo social e se destacou um sentido de negritude, o que envolve os desafios de ocupar espaços artísticos, políticos e acadêmicos que constituem estruturas fechadas e organizadas historicamente para exclusão. Mais tarde, este momento ressoará de diversos modos na criação de SobreVivo, inclusive na composição espacial de uma cena específica da montagem, que propõe localizações diferenciadas para pessoas pretas e pessoas brancas (como será descrito mais adiante neste artigo).

A proposta de lyá Sandrali de Òsún engendrou outro modo de configuração e ocupação do espaço, produzindo um discurso que desacomoda uma lógica social naturalizada. Assim, evidenciou a dimensão política e simbólica do espaço, que, em todas as suas dimensões, mais ou menos visíveis, é território de disputa, discurso e produção de imaginários, seja na disposição espacial de uma manifestação, das cidades, das pessoas, da sociedade ou da cena. O momento da reorganização dos corpos na Esquina Democrática revelou possibilidades de colocar em cena, em pauta, no foco principal, a juventude negra, o racismo institucionalizado e a própria espacialidade do poder, assim como brechas e interstícios que podem ser ocupados para a criação de outros horizontes de sociabilidade.

O teatro, arte do entre e do encontro, tem como matéria o espaço (e o tempo) em seu fazer criativo, o que atravessa múltiplas de suas dimensões: composição

\footnotetext{
${ }^{14}$ Ialorixá Sandrali Bueno de Òsún é o nome mítico social de Sandrali de Campos Bueno, iyálorisá, psicóloga e dirigente da Comunidade de Tradição de Matriz Africana, Sociedade Afro-brasileira Ilê Àsé Orisá Yemanjá, Batuque do Rio Grande do Sul.

${ }^{15}$ Como ocorrido nas manifestações por George Floyd, homem negro estadunidense assassinado por um policial no estado de Minneapolis no ano de 2020. Diversas manifestações ocorreram em decorrência de sua morte, tendo algumas também usado a tática do cordão humano de pessoas brancas como proteção. Disponível em: https://revistaforum.com.br/noticias/barreira-de-branco-apoiadores-fazem-paredao-entrepolicia-e-manifestantes-negros-emminneapolis/?fbclid=IwAR3XF9WksSRtlEiq8ZVkInIx0e5laCQ6005czyHkawQEAvou9lu_80PGuhs. Acesso em: 08 jun. 2020.
} 
espetacular interna, localização geográfica, trama ficcional, aspectos do real, dramaturgia, elementos concretos e simbólicos. Assim, compor teatralmente é compor com o espaço-tempo, o que faz da cena um campo fecundo para o exercício de composições poéticas e políticas que imaginam modos de ocupar (ou não) o espaço. Essas composições configuraram um eixo fundamental do processo criativo de SobreVivo, manifesto em desafios, desejos, deslocamentos, descobertas, reflexões, criações e inquietudes. Dinâmicas que marcaram o que denominamos como espacialidades inquietas do processo criativo e da montagem, que se dividem em alguns campos, sempre interconectados em um sistema complexo de retroalimentação: espaço urbano e festividade, espaços do eu e do nós - escrevivências e aquilombamento, espaços em trânsito e contexto de produção, espaços da cena - composições no local de apresentações.

\section{Espaço urbano e festividade}

O processo de criação de Sobrevivo - Antes que o baile acabe desenvolveuse em diferentes etapas, com variações na equipe e na proposta conceitual da montagem. Em termos de espaço cênico, a primeira etapa é marcada pela pesquisa e experimentação no centro da cidade, gerando duas intervenções urbanas; a segunda é definida pela intenção de montar um espetáculo teatral na rua, apresentado em fase processual no Viaduto do Brooklin em Porto Alegre; e a terceira configura-se pela decisão de direcionar a criação para um espaço fechado alternativo (que não fosse um teatro com palco e poltronas fixas) e pela redefinição e ampliação do elenco. Ainda que a montagem tenha transitado da rua e do espaço público para um espaço fechado e privado, a cidade permaneceu como imaginário e temática da criação, com suas pulsações, seus conflitos e encontros, cores e sons, corpos e falas - especialmente a fala de uma juventude negra, brasileira, da cidade de Porto Alegre, que tem buscado modos festivos de existir no ambiente urbano, marcado por tensões e enfrentamentos.

Ao pensar a cidade, não podemos esquecer que nossos centros urbanos foram constituídos a partir de marcos e normas que objetivam impor aos 
habitantes determinadas formas de viver, relacionar-se e produzir, por meio de um conjunto de recursos que incluem a organização espacial cotidiana e a hierarquia do poder impressa na própria arquitetura, com suas edificações verticalizadas, cercadas e distantes da população. As estruturas das cidades sulamericanas foram largamente erigidas com mão de obra escravizada, negra e indígena, desconsiderada do mundo que ela mesma construiu. Ainda hoje, no Brasil do século XXI, o projeto de extermínio do povo negro tem continuidade mediante o racismo estrutural, que mascara a desigualdade social, o encarceramento em massa, a repressão policial direcionada.

No entanto, a cidade também é palco de manifestações culturais, políticas, artísticas e sociais que articulam contrapontos à violência do poder, como as práticas de resistência dos povos negros da diáspora, incorporadas em expressões artísticas/culturais que atravessam gerações e continuamente reatualizam seus modos de existir e resistir. No hip-hop ou no samba, no carnaval ou no funk, no blues ou na capoeira, o povo negro constrói suas narrativas, produz suas histórias. Com frequência, essas produções constroem o enfrentamento às lógicas de dominação racista por meio de práticas festivas que elaboram mecanismos de celebração da vida e negociação com a morte, abrindo espaços nos interstícios do poder, aproveitando as frestas para fazer a festa que afirma existências excluídas das narrativas hegemônicas:

O espaço-tempo da festa abre portas a outras possibilidades de existência, nos permite imaginar outras realidades e, portanto, há sempre um risco de subversão; embora voltemos satisfeitos ao cotidiano, podemos também vislumbrar a possibilidade de transformá-lo. A experiência festiva sempre implica risco. Risco ou esperança. (Fagundes, 2010, p. 56).

O imaginário da festa como espaço de encontro e agente produtor de sentidos, "que traz morte e nascimento no mesmo fluxo" (Fagundes, 2010, p. 53), presente na noção de festividade na criação cênica, articulada pela artista e pesquisadora branca Patrícia Fagundes (2010), constituiu uma importante referência no processo criativo. A partir do reconhecimento da possibilidade de formação de microterritórios de sociabilidade e comunidades efêmeras pela 
criação teatral, a montagem buscou a composição de um espaço-tempo festivo compartilhado, de encontro e celebração da cultura negra, evidenciando suas próprias narrativas, que incluem o enfrentamento à branquitude e suas políticas de morte.

Neste tecer narrativo, o slam ofereceu-se como referência estruturante, tanto como procedimento de produção textual, quanto como modo de ocupar o espaço, que inventa ágoras possíveis na cidade para escutar e falar poesia. Criam-se espaços temporários de convívio ocupados festivamente por uma juventude periférica, que poeticamente entretece crítica social e reflexão pessoal em temáticas mobilizadas por seus próprios atores/autores. A atriz, poeta e pesquisadora negra Roberta Estrela D'Alva, uma das pioneiras da poetry slam no Brasil, assim define o movimento:

Poderíamos definir o poetry slam, ou simplesmente slam, de diversas maneiras: uma competição de poesia falada, um espaço para livre expressão poética, uma ágora onde questões da atualidade são debatidas, ou até mesmo mais uma forma de entretenimento. De fato é difícil defini-lo de maneira tão simplificada, pois, em seus 25 anos de existência, o poetry slam se tornou, além de um acontecimento poético, um movimento social, cultural, artístico, que se expande progressivamente e é celebrado em comunidades em todo o mundo. (D'Alva, 2011, p.125).

Ainda que tenha se originado na década de 80 em Chicago, em um bar situado nos arredores de um bairro de classe operária branca (D’Alva, 2011), no Brasil, o poetry slam com frequência ocupa espaços públicos para instaurar arenas de empoderamento para uma juventude negra continuamente excluída de espaços de protagonismo. Além do slam, batalhas de rap, campeonatos de skate, rodas de samba, saraus, festas de rua, etc. demarcam na cidade territórios temporários de celebração da vida, ocupados por existências acostumadas a lidar com a morte.

Essa efervescência urbana mapeou a trajetória criativa da montagem, tanto em seus aspectos mais vitais e transformadores quanto na consciência dos processos de exclusão e violência que ameaçam os percursos de pessoas negras na cidade. A cidade é território de disputa. Nos últimos anos, paralelamente ao nascimento e fortalecimento de vários movimentos de ocupação das ruas, cresce 
a ação de políticas neoliberais de privatização e "higienização" do espaço público que criminalizam e dificultam ações culturais e artísticas. Em Porto Alegre, o carnaval de rua do bairro Cidade Baixa, por exemplo, foi coibido de diferentes formas em 2018 e 2019, seja no afastamento dos blocos para locais mais distantes do Centro, seja no policiamento ostensivo e excessivo ou na proibição direta da Justiça. Sobre a questão, o artista e pesquisador negro Thiago Pirajira (2018, p. 1) analisa:

Importante pensar que existem diversos fatores que ocasionam tal situação, porém é impossível furtar-se de perceber que no grande jogo estrutural-racista em que vivemos, a festa do povo negro, onde os afetos se ampliam, as noções de convívio e fortalecimento se fundam e as identidades se potencializam, está mais uma vez sendo desarticulada em um jogo político que tem interesses em silenciar, coibir. Um jogo que se repete ao longo da história tendo a criminalização e o sucateamento como justificativa para o impedimento das expressões de sujeitos subalternizados. Um efeito da atualizada estrutura colonial em que vivemos.

Essa festa do povo negro, que "é memória, vida e continuidade para pretas e pretos" (Pirajira, 2018, p. 1) esteve sempre no horizonte da montagem - buscando a criação de um espaço de fortalecimento de narrativas de jovens negros, celebrando existências ao invés de apagá-las e entendendo a festa como elemento propulsor de outros modos de ver o mundo, que cria espaços de liberdade nos interstícios do poder. A busca por essa celebração cênica não exclui a crítica e o enfrentamento ao racismo. Um eixo importante de SobreVivo é a exposição de temáticas violentas, como o fato de que a cada 23 minutos um jovem negro é assassinado no país, assim como o confronto com o público, em questionamentos diretos aos espectadores brancos e seus privilégios em uma sociedade racista. Sem deixar de reconhecer a violência e a tragédia diária desta sociedade, a perspectiva festiva afirma a vida frente a políticas de morte, coloca em pauta e reivindica o bem-viver que deveria ser acessível a todos. Assim, a montagem busca afirmar e festejar a identidade de jovens negros e negras que ocupam a cidade criando tensões no espaço urbano - não como mortos em estatísticas, e sim como corpos políticos e poéticos que se expressam em cor, ritmo e afeto. 


\section{Espaços do eu e do nós - escrevivências e aquilombamento}

Como muitas propostas da cena contemporânea, Sobrevivo assume a atuação em primeira pessoa e estrutura a dramaturgia a partir de experiências e histórias pessoais dos atores e atrizes da equipe, entretecendo narrativas biográficas compartilhadas durante o processo de ensaios. Esse entretecer toma a memória como matéria constitutiva da criação, articulando espaços de reorganização da existência - somos fruto do que lembramos e também do que esquecemos. Vale considerar que a recorrente presença de material biográfico na criação artística contemporânea não define homogeneidade estilística ou processual, adotando modos, práticas e formas singulares, ainda que ressonantes. Em SobreVivo, uma montagem que se constitui a partir de narrativas e subjetividades de artistas negros que questionam o racismo estrutural da sociedade brasileira, o proceder biográfico toma como referência noções afrocentradas, como a escrevivência e o quilombismo, que inauguram e fomentam fluxos de comunicação entre espaços do eu e espaços do nós.

A escritora e intelectual negra Conceição Evaristo cunha o termo escrevivência a partir de sua própria trajetória de vida e criação, em articulação com a reflexão sobre a incorporação da vivência particular de quem escreve na literatura afro-brasileira, que evoca uma história coletiva impressa na particularidade, contrapondo narrativas eurocêntricas e imaginando "outra história, outro destino para os africanos que foram trazidos e escravizados nas Américas" (Evaristo, 2008, p.2). Segundo a autora, em entrevista à revista Nexo (2017), sua intenção não foi criar um conceito, ainda que trabalhasse com o termo desde 1995, em sua dissertação de mestrado. A escrevivência está relacionada à sua própria história e à intencionalidade de seu fazer literário, à memória individual e à memória social, à História e suas distorções:

Este termo nasce fundamentado no imaginário histórico que eu quero borrar, rasurar. Esse imaginário traz a figura da "mãe preta" contando histórias para adormecer a prole da Casa Grande. [...]. Quero rasurar essa imagem da "mãe preta" contando história. A nossa "escrevivência" conta as nossas histórias a partir das nossas perspectivas, é uma escrita que 
se dá colada à nossa vivência, seja particular ou coletiva, justamente para acordar a Casa Grande. (Evaristo, 2017, p. 1).

A escrevivência não se propõe como um recurso estilístico ou conceito abstrato, mas como um modo ético de constituir outros olhares para os acontecimentos mediante o processo criativo, inscrevendo no texto o lugar e a condição social e histórica de quem fala, especialmente perspectivas excluídas das narrativas oficiais, que propõem outras maneiras de existir. A memória assume um papel importante nessa escrita e, segundo a autora, marca a literatura afrobrasileira: "Vários são os textos em que a memória, recriando um passado, ocupa um espaço vazio, deixado pela ausência de informações históricas mais precisas" (Evaristo, 2008, p.2). É este espaço vazio que as narrativas do eu em SobreVivo buscar ocupar, através da escrevivência cênica dos atores e atrizes.

A escrita da cena se fez por um elenco negro tecendo suas próprias narrativas, em um espaço de troca de histórias pessoais, referenciais, desejos artísticos e revoltas com o racismo que estrutura e se infiltra em cada poro da sociedade brasileira. Durante os ensaios, esse material vivencial era compartilhado em relatos orais e escritos, jogos teatrais diversos, sendo exposto em formato de roda ou em situações de conversa do grupo. As histórias eram encenadas coletivamente, em um processo de recriação e sociabilização das experiências, e, mesmo quando já estruturadas na dramaturgia, inclusive depois de apresentações públicas, foram rearranjadas em acordos grupais. Cada artista contribuiu com um tanto de suas histórias de vida, múltiplas em sua constituição, particulares e ao mesmo tempo coletivas, entrelaçando espaços do eu e espaços do nós. O processo desenvolvido estrutura-se sobre esses encontros e trocas, buscando incorporar a força que dinâmicas de enegrecimento - que implicam o reconhecimento junto a um grupo e sua ancestralidade, a uma História e a um povo - têm em produzir afetos e comunidade.

Essa força soma-se à potencialidade, própria dos processos de criação cênica, de formação de microterritórios de sociabilidade a partir do convívio, da exposição, de dinâmicas relacionais, das práticas corpóreas, festivas e afetivas que 
se fazem presentes em processos de ensaios e que podem produzir comunidade (o que não exclui conflitos e atritos, constituintes de toda associação humana). No contexto de SobreVivo e de sua criação enegrecida, essa comunidade temporária assume a perspectiva de um aquilombamento artístico, um espaço coletivo onde outras realidades são possíveis, lugar de afirmação de tradições, ancestralidades, modos de criação, pensamento e pertencimento de pretas e pretos.

A referência dos quilombos, comunidades que constituíram outras formas de sociabilidade em todo o território brasileiro durante o longo período da escravização, oferece um suporte importante para pensar espaços sociais transformadores e antirracistas em nosso contexto. No início da década de 80, Abdias do Nascimento elabora o termo quilombismo como conceito, proposta política e imaginário libertário que projeta espaços de organização e fortalecimento do povo negro no Brasil, reconhecendo sua história de resistência e protagonismo na luta por uma sociedade mais justa. Essas outras formas de sociabilidade, distintas da lógica colonial, continuaram existindo através do tempo, infiltrandose de diversos modos na vida social como "genuínos focos de resistência física e cultural":

Objetivamente, essa rede de associações, irmandades, confrarias, clubes, grêmios, terreiros, centros, tendas, afoxés, escolas de samba, gafieiras, foram e são os quilombos legalizados pela sociedade dominante; do outro lado da lei se erguem os quilombos revelados que conhecemos. Porém tanto os permitidos quanto os 'ilegais' foram uma unidade, uma única afirmação humana, étnica e cultural, a um tempo integrando uma prática de libertação e assumindo o comando da própria história. A este complexo de significações, a esta práxis afro-brasileira, eu denomino de quilombismo. (Nascimento, 1980, p. 255).

Junto à escrevivência, a referência do quilombo como "reunião fraterna e livre, solidariedade, convivência, comunhão existencial” (Nascimento, 2009, p 206), espaço coletivo e comunitário que protege a própria existência individual e forja condições para assumir o "comando da própria história", favoreceu a importante conexão entre espaços do eu e do nós no processo criativo de Sobrevivo. Tal conexão é fundamental em experiências de sociabilidade, como é o caso da criação cênica colaborativa e compartilhada. Na montagem, a intersecção entre jovens negros, tanto em ensaios quanto em apresentações, promoveu processos 
de entender-se comunidade por meio do teatro, em ciclos de retroalimentação entre fazer teatral e aquilombamento. O espaço quilombo articulado acolheu e dialogou com os desejos de criação de um coletivo que buscou desenvolver uma proposta teatral antirracista, que encontrasse ressonância em espectadores negros e desacomodasse o racismo de espectadores brancos.

A ideia de aquilombamento revelou-se também imprescindível como construção de um espaço seguro para o compartilhamento de vivências relacionadas a racismo e negritude, com frequência muito dolorosas, já que as experiências de jovens negros, de mulheres negras, de homossexuais negros brasileiros, identidades presentes no grupo, são marcadas por perigo e violência. Assim, a criação de um espaço aquilombado de cuidado, afeto e escuta constituiu uma demanda e um desafio constante durante todo o processo. Forjar um lugar seguro de produção e significação de outras narrativas, distintas das normativas brancas do poder, um espaço de encontro que estimule e fortaleça outros imaginários, em que jovens negros produzem e poetizam suas próprias existências, é compor um espaço político que ocupa e busca alargar brechas, interstícios, fissuras, no sistema vigente de dominação. Como aponta o artista negro Rincon Sapiência na música Ponta de Lança ${ }^{16}$, talvez uma das maiores transformações antirracistas seja fazer com que a racista sociedade brasileira perceba que pessoas negras se relacionam afetivamente, amorosamente, que estão juntas, produzindo afetos e espaços de coletividade.

\footnotetext{
Meu verso é livre, ninguém me cancela

Tipo Mandela saindo da cela Minhas linha voando cheia de cerol E dá dó das cabeça quando rela nela Partiu para o baile, fugiu da balela Batemos tambores, eles panela Roubamos a cena, não tem canivete As patty derrete que nem muçarela Quente que nem a chapinha no crespo Não, crespos estão se armando Faço questão de botar no meu texto Que pretas e pretos estão se amando
}

${ }^{16}$ Disponivel no link. https://www.youtube.com/watch?v=vau8mq3KcRw. 
A música de Rincon não estava diretamente presente no espetáculo, mas integra um importante repertório de referências artístico-culturais que alimentou o processo criativo, composto por musicalidades, ritmos e corporeidades afrobrasileiras, do batuque ao funk carioca, do samba ao rap. Tal repertório com frequência evoca espacialidades distintas à frontalidade do palco italiano, propondo composições mais circulares, hierarquias menos verticalizadas e mais movediças, variações de ponto de vista e localização. Muitas dessas referências chegaram, inclusive, a constituir a estrutura da montagem, que começa com um fragmento cantado à capela da canção o que se cala, de Elza Soares, seguida por uma coreografia coletiva para a música Preto Prata, de Baco Exu do Blues, e logo pela encenação de fragmento textual de A missão em fragmentos: 12 cenas para descolonização em legítima defesa, espetáculo com direção de Eugênio Lima. Tais incorporações integram a proposta de enegrecer a cena e de aquilombar-se, no caso, mediante reconhecimento e celebração de produções artísticas afrocentradas. Neste movimento, o slam colocou-se novamente como um importante componente, que dialoga tanto com a escrevivência quanto com o imaginário do quilombo e da organização circular, do estar em roda.

Nas ágoras festivas inventadas por eventos de slam que ocupam a cidade, jovens negros encontram um espaço de difusão de seus saberes, vozes, problemáticas; em experiências de aquilombamentos temporários. É na potência do encontro que o slam se constitui, característica que também é compartilhada com o teatro e que oferece fortes recursos criativos e políticos, como sugere Estrela D’Alva (2014, p. 120):

O slam é feito pelas e para as pessoas. Pessoas que, apropriando-se de um lugar que é seu por direito, comparecem em frente a um microfone para dizer quem são, de onde vieram e qual o mundo em que acreditam (ou não). É um espaço para que o sagrado direito à liberdade de expressão, o livre pensamento e o diálogo entre as diferenças sejam exercitados. Um espaço autônomo onde é celebrada a palavra, a fala e algo ainda mais fundamental num mundo como o que vivemos: a escuta. 
Há muito de escrevivência no exercício criativo do slam presentes em SobreVivo, seja como dramaturgia textual em algumas cenas, seja como inspiração de um proceder artístico que se deseja político, sensível, festivo e enegrecido. Entre outras manifestações de juventudes negras na cidade, o slam articula possibilidades de afirmação de enegrecimento, um espaço móvel que produz narrativas festivas e de contraste à lógica vigente de dominação racial. Narrativas de enfrentamento. Narrativas de esperança.

\section{Espaços em trânsito e contexto de produção}

A criação cênica dialoga continuamente com materialidades e incertezas, diversas delas relacionadas com os múltiplos elementos constitutivos dos artistas envolvidos, especialmente em processos que se propõem colaborativos e com hierarquias flexíveis. É na negociação entre esses múltiplos elementos que se constitui grande parte do processo criativo, tanto na busca de estruturas e escolhas, quanto na abertura às turbulências e dúvidas. Como já mencionado, o processo criativo de Sobrevivo foi marcado por trânsitos: de uma temática política mais geral para o foco em questões raciais, entre diferentes equipes, da rua para um espaço fechado.

Desde as primeiras etapas da criação, o desejo era ocupar um espaço que não fosse do tipo italiano, com plateia e palco fixados em uma relação frontal entre artistas e espectadores. A própria denominação desse modelo já evoca sua herança eurocêntrica, que favorece certas relações e produções de sentido. A ideia do grupo era justamente afastar-se desse legado e buscar a afirmação de outras perspectivas. Ainda que a crítica ao modelo italiano e a experimentação em outros espaços tenham marcado a História do teatro do século XX, a maior parte dos edifícios teatrais no Brasil (e provavelmente no mundo) continua seguindo esse modelo. Assim, fugir a esse padrão estrutural permanece um desafio, que inclui nossos modos de ver, estar e pensar, além do agenciamento de condições concretas para viabilizar outras ocupações. Em outras palavras, condições de produção. 
Os meios de produção, com considerável frequência, são desconsiderados ao se pensar em processos de criação cênica, como se a criação artística não estivesse relacionada a um contexto econômico, político, social e histórico, e não fosse parte de seu próprio discurso o diálogo com esse contexto a partir de sua localização. É possível que essa desmaterialização se relacione ao fato de que muito do que estudamos como História do Teatro seja ainda a história do teatro europeu e de que as referências de grupos e artistas para nosso fazer teatral, ainda hoje no Brasil, continuem sendo da Europa e dos Estados Unidos - em grande parte, de grupos e artistas renomados que circulam em grandes festivais e circuitos da Europa e dos Estados Unidos, dispondo de condições e verbas muito distantes de nossa realidade, tão distantes que não são nem mencionadas. Nesse aspecto, também se reproduz o mecanismo colonial de inferiorização: reverenciamos o grande teatro europeu e lamentamos nossa precarização, como se fosse nossa responsabilidade e como se produzíssemos um teatro menor, em comparações cujos critérios permanecem ocultos. Não produzimos um teatro menor, tampouco nos interessa a comparação, pois precisamos fortalecer nossos próprios parâmetros, nossos próprios modos de agenciar o tempo-espaço a partir de nosso contexto.

Na vida e na arte, é necessário pensar em quem paga a conta, como e por quê. As relações de produção que constituem uma obra cênica são parte de seu discurso, não um mero entrave ou uma sorte do destino. O sistema capitalista em que vivemos, que produz e se alimenta do racismo, também vende e lucra com camisetas antirracistas, o que, além de dividendos, produz apaziguamento. A arte também pode ser parte desse esquema de consumo e anestesia social. É tempo de pensar a criação teatral em nossos termos, articulando nossos próprios saberes, referências, modos de pensamento e práticas criativas.

Como grande parte da criação cênica brasileira, SobreVivo lidou com a precariedade socialmente imposta, tanto ao teatro e à universidade pública quanto à população negra e pobre do país. Os recursos financeiros vieram de duas fontes: a metade da ajuda de custo para uma apresentação no Dia da Cultura da UFRGS ${ }^{17}$ 
(mais especificamente, 400 reais) e o investimento pessoal dos dois integrantes que respondiam pela pesquisa de mestrado e pelo estágio de graduação, Sandino Rafael e Phillipe Coutinho, em diversos gastos de produção (1.022,79 e 1.147,98 reais, respectivamente). Na conta, poderíamos incluir os gastos pessoais, não contabilizados, de todo o elenco para deslocar-se e estar presente em ensaios, o que supõe, por exemplo, gastos de alimentação. Para uma equipe de artistas estudantes cotistas, tais gastos não são desprezíveis.

Por outro lado, além do aporte monetário direto, SobreVivo contou com a riqueza de importantes recursos constituintes de grande parte da criação cênica brasileira: gente, tempo, espaço e redes de colaboração. Em suas diferentes etapas, o projeto se fez do investimento criativo, emocional, corpóreo e intelectual de diversas pessoas, que dedicaram parte de sua vida ao seu desenvolvimento, principalmente os artistas da equipe central. Também contou com espaço e tempo para ensaios no prédio do DAD/UFRGS, com a colaboração e suporte das professoras orientadoras, com o empréstimo de espaço para apresentações, com o empréstimo de equipamento de som, com o olhar e estímulo de pessoas amigas. Esse conjunto de elementos também integra os recursos de produção do espetáculo, que dialogam com o contexto social, histórico, econômico e político no qual estamos inseridos.

As condições de produção foram um dos elementos que contribuíram para o trânsito do projeto da rua para um espaço fechado. Durante as primeiras etapas do projeto, a intenção era ocupar a rua, mais especificamente, lugares do centro da cidade no período noturno. Juntar-se, formar corpo com os movimentos jovens de ocupação urbana, integrar a festa por meio do teatro. O local previsto para a estreia era o Viaduto do Brooklin, situado em uma interseç̧ão de grandes avenidas, próximo ao Campus Central da UFRGS e palco de diversos eventos alternativos, como rodas de samba, competições de skate, festas, slam, etc. No dia 25 de outubro de $2018^{18}$, foi realizada uma apresentação nesse local como ensaio aberto, tendo havido uma situação imprevista que se revelou muito

${ }^{18} \mathrm{Na}$ qualificação do projeto de mestrado envolvido. 
significativa.

A apresentação foi realizada após uma fala do ex-candidato à presidência Guilherme Boulos, sobre a qual o grupo não tinha conhecimento alguns dias antes e que reuniu várias centenas de pessoas, no contexto acirrado do segundo turno eleitoral de 2018. Em virtude dessa circunstância, o público foi bem maior do que o esperado, fazendo com que uma apresentação pensada para ser uma mostra de um espetáculo em processo, em uma quinta-feira qualquer, se tornasse um acontecimento cênico especial, potencializado pelo contato com um público numeroso e entusiasmado. -

Por outro lado, várias dificuldades estruturais do projeto evidenciaram-se, como a precariedade do equipamento de som adquirido com os parcos recursos financeiros, ineficaz em um espaço amplo, com ruído de trânsito e das pessoas que por ali estavam. Tentou-se contornar essa dificuldade com o uso do equipamento de som do ato, bem mais potente e profissional, gentilmente cedido pelos organizadores. No entanto, tampouco foi efetivo, pois os atores não tinham intimidade com os microfones, de modo que não os utilizavam corretamente - a voz permanecia pouco audível. O posicionamento das caixas de som também não estava de acordo com as necessidades espaciais da montagem.

Figura 1 - Apresentação realizada no Viaduto do Brooklin em 25 out. 2019. Foto: Débora Alemand

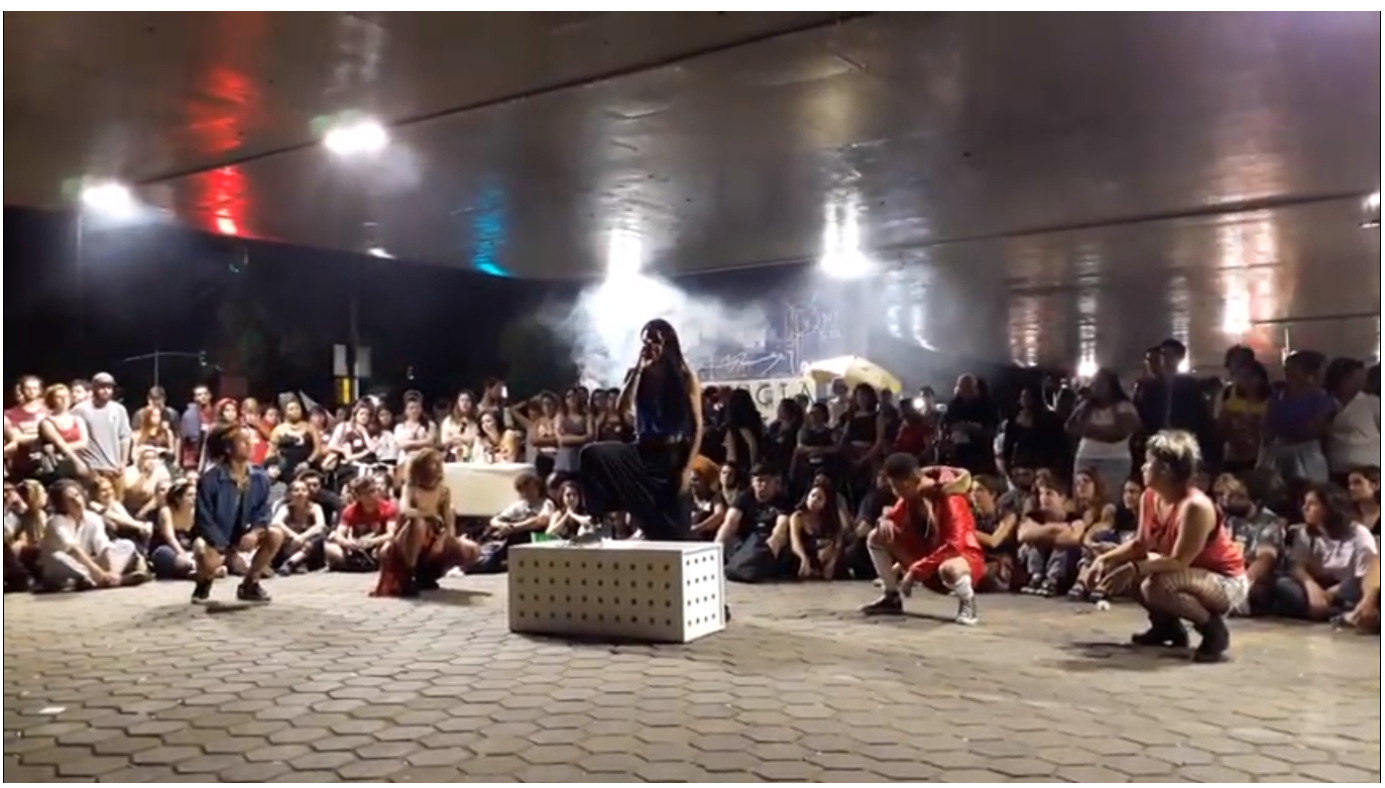


Após a apresentação, as questões de condições técnicas continuaram reverberando em discussões e dúvidas: como realizar uma montagem na rua, no período noturno, que pretendia instaurar um universo de festa urbana, sem verba para equipamentos adequados de sonorização e iluminação cênica? Outro fator adverso eram as restrições e coibições que a realização de festas e eventos de rua em Porto Alegre vinha sofrendo, mediante normativas do poder público na direção de privatização do espaço comum.

Em um período entre o final de 2018 e o início de 2019, a equipe sofreu uma transformação que define um marco no processo de criação de SobreVivo. No que denominamos como segunda etapa do processo (a primeira é definida pelo ciclo de intervenções urbanas, com participantes variados), o elenco era composto por Esly Ramão (ator, educador, slammer), Julia Santos (atriz, figurinista), Manoel Luthiery (aluno do mestrado, bailarino, coreógrafo, futuro professor universitário de danças negras), Suzane Cardoso (M.C, atriz, professora, mãe) e Phillipe Coutinho (ator, iluminador, poeta). No final de 2018, Manoel e Julia saíram do projeto devido a outros compromissos. Com a radicalização da questão racial, Suzane, a única atriz branca, optou por afastar-se da montagem. Após uma pausa, em março de 2019, retomaram-se os ensaios com novos integrantes no elenco: Cira Dias (ator) Gabriel Farias (ator, arte-educador), Letícia Guimarães (atriz, passista e coreógrafa da Imperadores do Samba) e Mayara Marques (atriz). Assim, o elenco final do espetáculo é composto por Cira, Esly, Gabriel, Letícia, Mayara e Phillipe.

É esse conjunto de atores e atrizes que, junto ao diretor Sandino Rafael, em maio de 2019, decidiu o trânsito da montagem da rua para um espaço fechado. Além das dificuldades de produção, o processo em sala de ensaio não estava imaginando a rua como espaço futuro da criação; a espacialidade, a corporeidade e a vocalidade desenvolvidas nas composições partiam, consideravam e jogavam com o espaço fechado da sala. Desse modo, foi necessário fazer uma escolha, pois os mapas seriam distintos de acordo com o destino escolhido. Após muito debate, o grupo decidiu realizar o espetáculo em um espaço fechado: no Lugar, ateliê de criação do artista e professor da UFRGS Chico Machado, que cedeu gratuitamente o uso para ensaios e apresentações. A urbanidade e ações na cidade 
continuaram como fontes de inspiração, mas a montagem migrou para esse lugar alternativo, onde em princípio seria possível realizar uma festa em conjunto com apresentações, assim como experimentar outras relações espaciais que não a do modelo de edifício teatral italiano.

O Lugar é uma espécie de porão de um prédio na Independência (zona central de Porto Alegre), que oferece um espaço livre sem divisórias de aproximadamente $70 \mathrm{~m}^{2}$, com pé direito alto. No fundo, um balcão define a área de bar/cozinha; logo adiante, os banheiros; e, ao fundo, um pequeno pátio. O espaço, como a rua, não conta com equipamento de iluminação e sonorização cênicas, nem condicionamento acústico. No entanto, é mais factível sonorizar e iluminar um espaço fechado que dispõe de energia elétrica do que um espaço público aberto (parte da exígua verba de produção foi dedicada ao aluguel de alguns refletores para apresentações). Além da festa, migrar para o Lugar favorecia a possibilidade de certos desejos cênicos: proximidade com o público, realização de cenas mais intimistas, cena no escuro, ensaios no local, desenvolvimento textual mais extenso.

No início de julho de 2019, a equipe passou a ensaiar prioritariamente no local, realizando apenas alguns ensaios ainda no DAD. Antes de transferir-se, o grupo teve a oportunidade construir no Lugar a plataforma de madeira que consiste no principal elemento cenográfico da montagem, possibilitando um significativo período de experiências criativas com ela. SobreVivo estreou no dia 15 de setembro do mesmo ano, em apresentação vinculada à defesa do Memorial Crítico Reflexivo do mestrado de Sandino Rafael. Ainda em 2019, o grupo faria três apresentações no Lugar, na ocasião do Estágio de Atuação de Phillipe Coutinho, nos dias 11, 18 e 19 de outubro. Todas as apresentações, em espaço alternativo, mas parte de atividades acadêmicas, foram realizadas com entrada franca e abertas ao público em geral. Nesta nota de rodapé ${ }^{19}$, o registro em vídeo da montagem (cuja qualidade tecnológica, é preciso dizer, corresponde às suas condições de produção).

${ }^{19}$ Vídeo de registro da montagem disponível em: www.youtu.be/xyJd355ihlE 


\section{Espaços da cena - composições no local de apresentação}

Uma inquietude continuamente renovada da montagem esteve centrada na questão da composição espacial na cena, considerando sua articulação discursiva com os elementos do fazer teatral que produzem narrativas em sua própria organização estética - níveis, profundidade, disposição em relação ao público, espaço cênico, distâncias, corporeidade, imagens, e também ritmos, velocidades, durações, já que tempo e espaço são dimensões inseparáveis na composição cênica. Parte dessa questão está relacionada à "marcação", termo que não pode ser reduzido a deslocamentos e posicionamentos mecânicos de pessoas na cena. A ocupação do espaço, os lugares de onde falamos, as trajetórias que desenhamos, as relações espaciais com outros corpos e coisas, não são "neutras" - produzem narrativas na cena e no mundo.

Diversos desafios específicos em relação à composição espacial apresentaram-se no período de ensaios e apresentações no Lugar, local de apresentações descrito na seção anterior. Em um primeiro momento, o grupo reconheceu certa paralisia na movimentação e ausência de marcações que produzissem sentidos articulados com os pensamentos desenvolvidos, como se houvesse uma quietude nos espaços e corpos que não correspondia à inquietude das reflexões críticas tecidas. Então, o desenho espacial da cena recebeu atenção especial, com a exploração de jogos e dinâmicas de composição e ocupação do espaço. A seguir, percebeu-se que a montagem transitava a outro extremo, com movimentações excessivas que, em alguns momentos, fragilizavam os temas tratados. Tal trânsito entre extremos não é incomum em processos de criação cênica, em que é preciso perder a medida para encontrar o ponto, aventurar-se no risco para traçar possíveis caminhos. Entre a pausa e a inquietude, o silêncio e o grito, a imobilidade e a explosão de movimento, o ponto e o contraponto, SobreVivo criou suas dinâmicas espaço-temporais, compondo um espaço festivo que é também de friç̧ão e protesto.

Junto aos corpos dos atores e atrizes, e dos próprios espectadores no entre da cena, um elemento cenográfico contribuiu na criação de muitos movimentos e composições: a plataforma de madeira, construída no próprio espaço de ensaios 
e apresentações. Era uma estrutura básica que oferecia variação de níveis, transformações no espaço, em ações concretas e imaginadas. O grupo idealizou essa estrutura e relacionou-se com ela durante boa parte do processo, o que acabou por contribuir na dramaturgia, em especial nas transições entre uma cena e outra. A partir da plataforma, conseguiu-se projetar movimentações e dinâmicas que articulam diferentes imagens e ações: um palanque para manifestos, depoimentos e discursos; uma barreira em uma cena que retrata as violências vividas em comunidades periféricas; um grande objeto que exige engajamento de todo o elenco na atividade de transportá-lo; uma zona de encontro que reúne o grupo em imagens diversas, muitas delas reforçando a ideia de coletividade, tão cara ao trabalho.

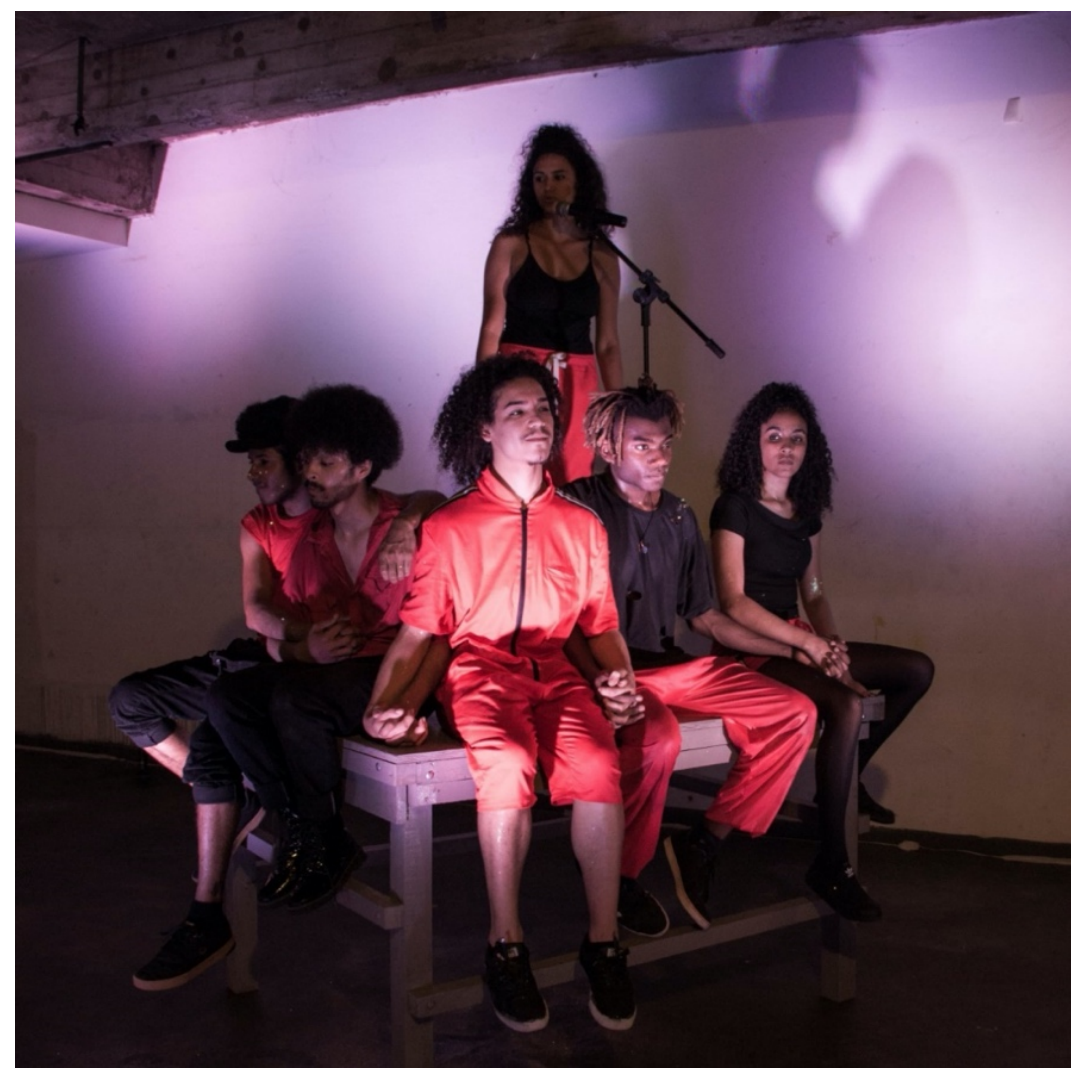

Outro aspecto constituinte da composição espacial de SobreVivo é o das coreografias e das danças não estruturadas, nascidas do próprio repertório de 
referências, vivências e desejos do elenco, um grupo jovem e dançante. Em termos de coreografias, as mais significativas são a recriação de Everybody Mad, de Beyoncé (do Festival Coachella 2018), e uma coreografia do grupo, sob direção de Letícia Guimarães, para Preto Prata, de Baco Exu do Blues. Além dessas, há diversos momentos dançantes na montagem que colocam em cena o funk proibidão, o pop, o prazer e a força vital de corpos que se relacionam e pulsam em festa.

Figura 3 - Apresentação no Lugar, 19 out. 2019. Foto: Pedro Spiker

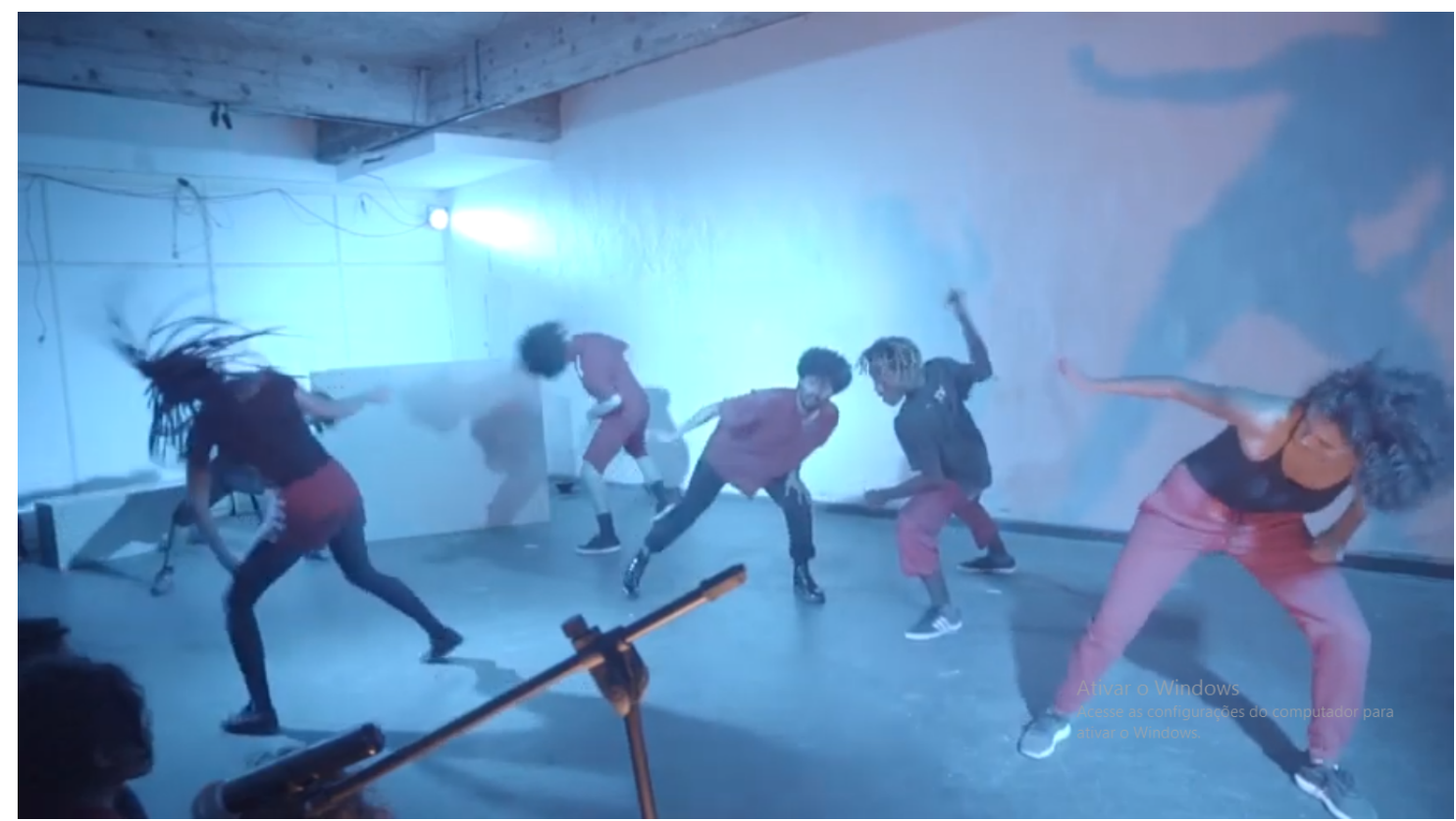

Ao ocupar o Lugar, uma questão basilar foi decidir o posicionamento do público. Interessava ao grupo a relação de proximidade física com o espectador, o que possibilitaria a realização de diálogos diretos com as pessoas presentes. Diferentemente de um teatro com cadeiras fixas, a escolha da organização espacial definiria também a capacidade de público, prevista em 60 pessoas. Ao buscar evitar a dinâmica de palco italiano, a proposta era não delimitar locais específicos para plateia, deixando as cadeiras disponíveis empilhadas em um canto, de preferência apenas para pessoas com dificuldade de permanecer em pé ou sentadas no chão (ainda que o acesso às cadeiras não fosse proibido). A intenção era provocar deslocamentos do espectador, fazendo-o questionar a si 
mesmo que posição assumiria no espetáculo. No entanto, as apresentações demonstraram que o posicionamento inicial da plataforma cenográfica, dos refletores que compunham a iluminação e dos operadores de som e luz acabava sugerindo ao público determinadas localizações. Em um primeiro momento, o grupo reagiu tentando driblar essas sugestões, imaginando mecanismos que pudessem forçar o público a deslocar-se, a desacomodar-se. No entanto, tais deslocamentos pareciam externos e automatizados, e o grupo decidiu investir no conceito de desacomodar por meio de ações, falas e cenas específicas que articulam discursos e poéticas através de certas espacializações.

Nesse sentido, entre a primeira apresentação, em setembro, e as apresentações de outubro, cenas foram criadas ou rearranjadas. Em uma delas, as pessoas negras presentes na plateia são carinhosamente convidadas para uma roda no centro da área cênica, de mãos dadas com o elenco. É entoada a canção Bará Agelu, tradicional em práticas religiosas de matriz africana. Na afirmação de uma percepção aquilombada de pertencimento e coletividade, busca-se a composição de uma atmosfera de proximidade e afeto entre as pessoas negras presentes. As pessoas brancas não entram na roda, permanecem na parte externa do círculo. Esse movimento de cena pressupõe uma perspectiva de racialização do público, separando visivelmente o público branco do público negro.

Além dessa cena, a intenção de racializar e evidenciar a branquitude articulase de outras formas na composição espacial do espetáculo, como no direcionamento próximo e direto de falas críticas a espectadores brancos; em uma cena em blecaute em que ruídos ameaçadores são produzidos do lado de espectadores brancos; no momento em que um ator anuncia que estão todos trancados naquele espaço. Próximo do final da montagem, o ator Gabriel Farias enuncia:

Acabou, não é ficção. É tudo friç̧ão. Eu quero que, quando vocês saírem por essa porta, vocês pensem onde vocês estão pisando. Em que calçada vocês tão pisando. Quem construiu essa calçada, quem construiu aquele prédio, quem construiu esse prédio, escutem esse prédio, escutem o que a gente tá dizendo, escutem o som de hoje, se localizem, escutem o som de hoje. Esse é o som do (som do dia), é o dia em que mais um tijolo foi tirado dessa estrutura racista. Se localizem e entendam que a herança da escravidão atravessa todo mundo aqui dentro. Todo mundo. (Farias apud Rosa, 2019, p.123). 
De vários modos, os jovens artistas de SobreVivo urgem que as pessoas brancas se localizem, percebam privilégios e o próprio racismo, mesmo que disfarçado. Esta urgência ressoa e forma corpo com as reivindicações históricas do movimento negro e com ideias e propostas especialmente recorrentes em nosso tempo, como a noção de lugar de fala, relacionada justamente à localização social das pessoas. A filósofa e intelectual negra Djamila Ribeiro, em sua popular obra O que é Lugar de Fala?, ressalta que:

O fundamental é que indivíduos pertencentes ao grupo social privilegiado em termos de locus social consigam enxergar as hierarquias produzidas a partir deste lugar e como este lugar impacta diretamente na constituição dos lugares de grupos subalternizados. Numa sociedade como a brasileira, de herança escravocrata, pessoas negras vão experienciar racismo do lugar de quem é objeto desta opressão, do lugar que restringe oportunidades por conta desta opressão. Pessoas brancas vão experienciar do lugar de quem se beneficia desta mesma opressão. Logo, ambos os grupos podem e devem discutir estas questões, mas falarão de lugares distintos. (Ribeiro, 2017, p. 86).

No teatro, esses lugares e posições podem ser corporificados e espacializados, como um pensamento-matéria em movimento. Na cena de Sobrevivo, os corpos contam histórias, evocam mortes e festas, provocam encontros e confrontos. Um corpo coletivo que pulsa. Corpos de jovens negras e negros, atravessados por constantes enfrentamentos com violências e opressões, e também corpos plenos de outras potencialidades, que, negociando com a morte, produzem festividade, cor, ritmo, arte, memórias. Espaços de cuidado e afeto, mas também de crítica, denunciando a estrutura racista que criminaliza e assassina todos os dias. No final do espetáculo, em um momento de atmosfera mais íntima e sensível, a atriz Maya Marqz enuncia: "queria que não vissem só raiva em nossos corpos, mas que também entendessem o motivo de nossa raiva." (Marqz apud Rosa, 2019, p.124). 
Figura 4 - Apresentação no Lugar, 15 set. 2019. Foto: Diogo Vaz

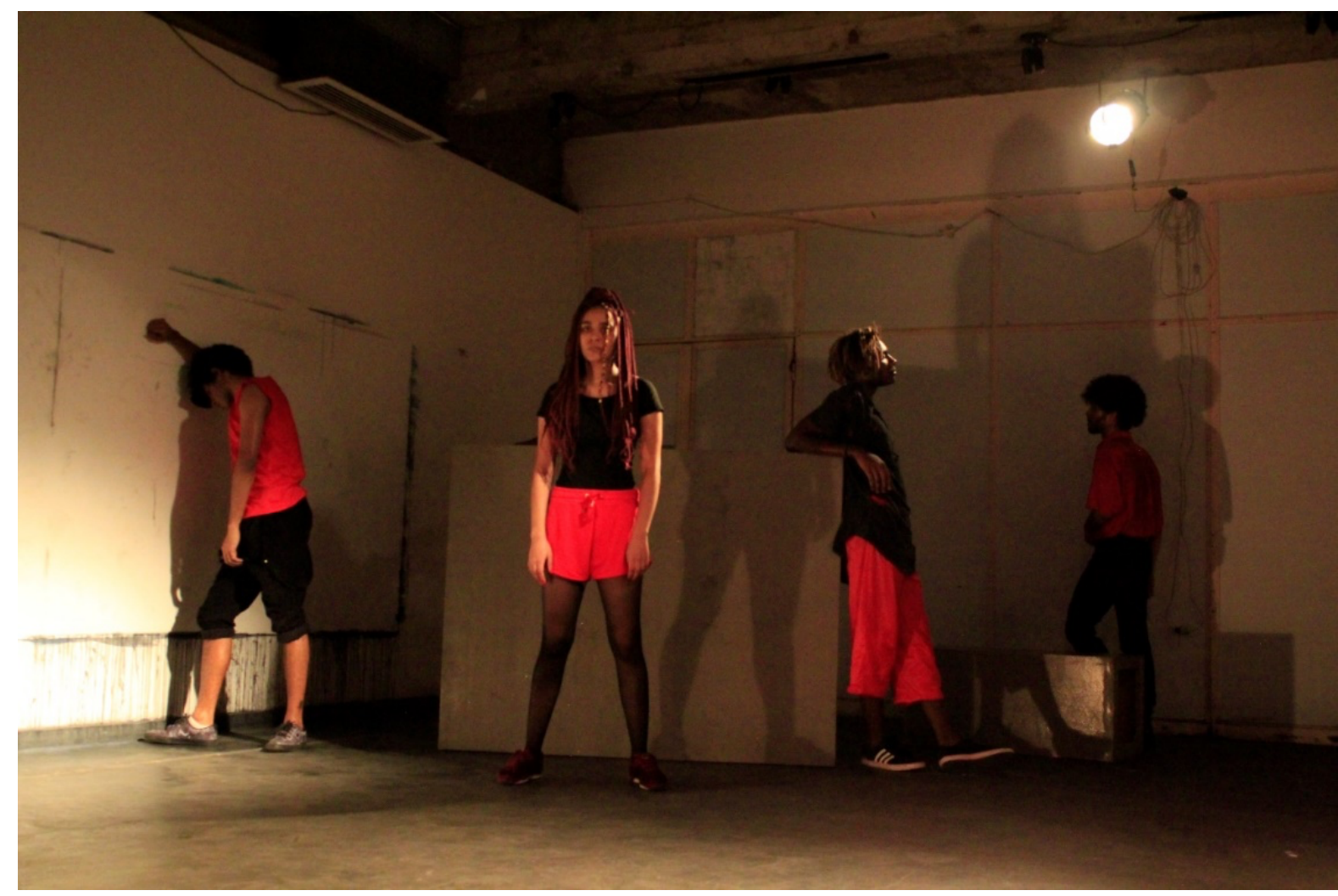

Este texto é um testemunho de um processo de criação que coloca no tempo-espaço da cena e do mundo inquietudes e urgências de um coletivo jovem de pretos e pretas que, por meio da arte, clamam por transformação social. Nesse clamor, articulam festividade, manifesto, escrevivência, slam, aquilombamento, ancestralidade, dança, memória, amor e fúria, afirmando o teatro como espaço político de encontro e criação de outros imaginários, como ação que forja microterritórios de sociabilidade onde outras realidades são possíveis. Em face da violência social, a criação cênica se oferece como espaço político e poético de experiência e enunciação de narrativas alternativas à lógica da branquitude. Na inquietude de quem historicamente foi cerceado de estar em espaços como o teatral, o coletivo de criação de Sobrevivo faz uso desse espaço como uma arena possível que pode ser a última, o baile derradeiro para mostrar a cor, o passo, a voz, que vem do jeito que é para vir, agressiva, consciente, corrosiva, sensível, enegrecida, inquieta. 
Figura 5 - Parte da equipe em ensaio fotográfico realizado na metade do processo de SobreVivo. Em cima, da esquerda para a direita: Gabriel Farias, Maya Marqz, Suzane Cardoso, Sandino Rafael. Embaixo, da esquerda para a direita: Julia Santos, Letícia Guimarães, Phillipe Coutinho.

Foto: Diego Vaz

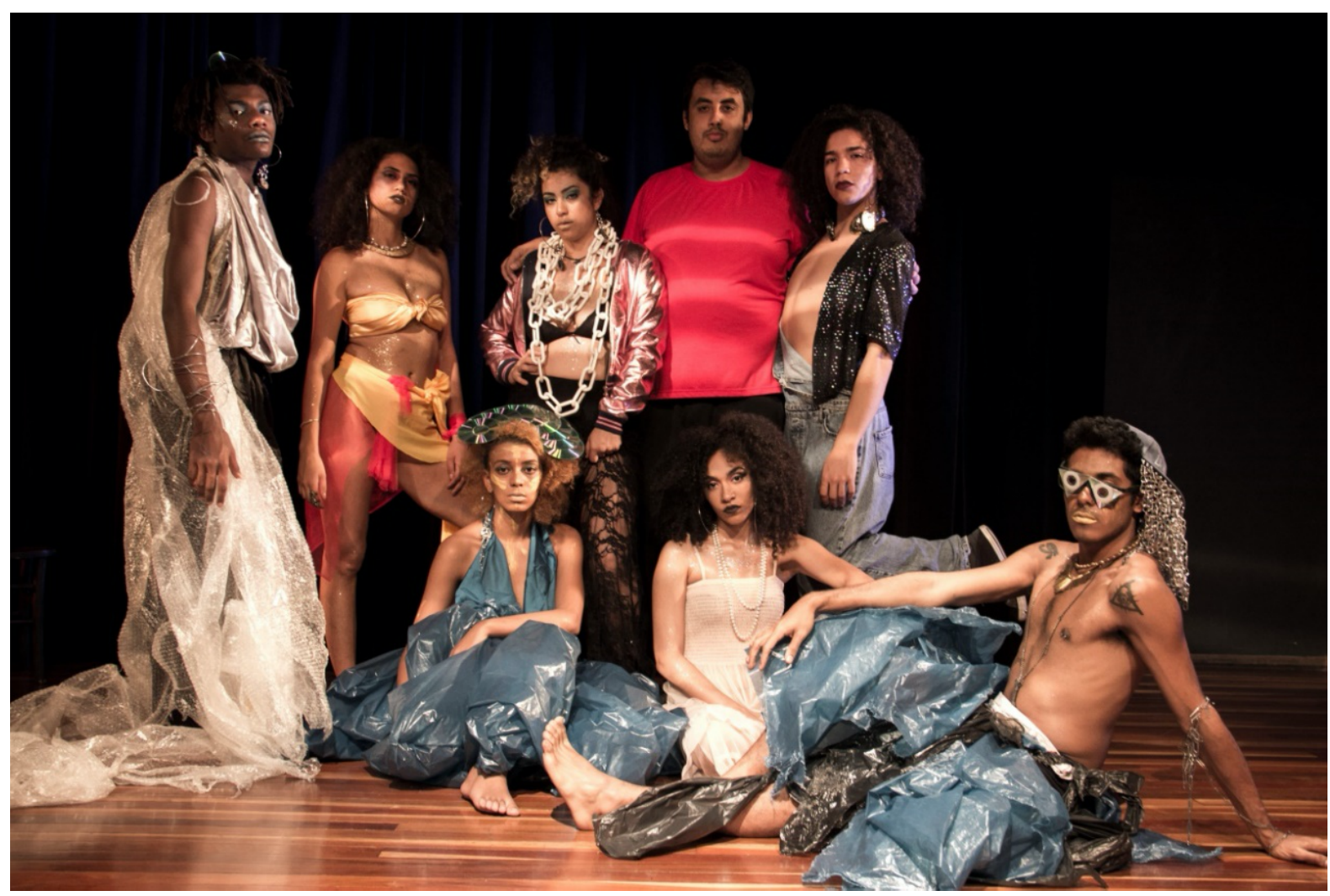

Referências

ALCÂNTARA, Celina Nunes de. Fala negra: um trabalho vocal para teatro como ato político. Repertório, Salvador, ano 21, n. 30, p. 281-295, 2018.1

BARRETO, Raquel. Uma pensadora brasileira. Revista Cult, 3 julho 2019. Disponível em: https://revistacult.uol.com.br/home/lelia-gonzalez-perfil/. Acesso em: 5 agosto 2029.

CARNEIRO, Sueli. Enegrecer o feminismo: a situação da mulher negra na América Latina a partir de uma perspectiva de gênero. Em HOLLANDA, Heloisa Buarque. Pensamento Feminista. Conceitos Fundamentais. Rio de Janeiro: Bazar do Tempo, 2019. 
ESTRELA D’ALVA, Roberta. Um microfone na mão e uma idéia na cabeça - o poetry slam entra em cena. Synergies Brésil. n. 9, p. 119-126, 2011.

ESTRELA D’ALVA, Roberta. Teatro Hip-Hop. São Paulo: Perspectiva, 2015.

EVARISTO, Conceição. Conceição Evaristo: Minha escrita é contaminada pela condição de mulher negra. Nexo Jornal, [S. l.], p. 1, 26 maio 2017. Disponível em: https://www.nexojornal.com.br/entrevista/2017/05/26/Concei\%C3\%A7\%C3\%A3o-

Evaristo-\%E2\%80\%98minha-escrita-\%C3\%A9-contaminada-pelacondi\%C3\%A7\%C3\%A3o-de-mulher-negra\%E2\%80\%99.

Acesso em: 29 maio 2020.

EVARISTO, Conceição. Escrevivências da afro-brasilidade: história e memória. Releitura, Belo Horizonte, n. 23, 2008. Disponível em: $<$ http://nossaescrevivencia.blogspot.com/2012/08/escrevivencias-da-afrobrasilidade.html> Acesso em: 12 jul. 2019.

FAGUNDES, Patrícia. La Ética de la Festividad en la Creación Escénica . 2010. 567 p. Tese (Doutorado)- Facultad de Humanidades Comunicación y Documentación, Universidad Carlos III, Madrid, Espanha, 2010. Disponível em: https://earchivo.uc3m.es/handle/10016/7557. Acesso em: 24 maio 2018.

LIMA, Eugênio. A missão em fragmentos: doze cenas de descolonização em legítima defesa. São Paulo: N-1 edições, 2017.

NASCIMENTO, Abdias do. O genocídio do negro brasileiro: processo de um racismo mascarado. Rio de Janeiro: Paz e Terra, 1978.

NASCIMENTO, Abdias do. O quilombismo: Documentos para uma militância panafricanista. 1. ed. Petrópolis: Vozes, 1980. v. 1.

RIBEIRO, Djamila. O que é Lugar de Fala?. Belo Horizonte: Letramento, 2017.

PIRAJIRA, Thiago. A resistência do povo negro? Carnaval consciente, Carnaval guerreiro. Gaúcha ZH, Porto Alegre, 12 fev. 2018. Disponível em: https://gauchazh.clicrbs.com.br/opiniao/noticia/2018/02/thiago-pirajira-aresistencia-do-povo-negro-carnaval-consciente-carnaval-guerreirocjdkfe7nd00zf01rva1fd55x4.html. Acesso em: 13 mar. 2019.

ROSA, Sandino Rafael da Silva. SobreVivo: Trajetórias de uma encenação enegrecida. Orientador: Patrícia Fagundes. 2019. Memorial crítico reflexivo (Mestrado em Artes Cênicas) - PPGAC/UFRGS, Porto Alegre, 2019. Disponível em: https://lume.ufrgs.br/handle/10183/204935. Acesso em: 18 jun. 2020.

SOUZA, Neusa Santos. Tornar-se negro: As vicissitudes da ldentidade do Negro Brasileiro em ascensão social. Rio de Janeiro: Graal, 1983. 
Recebido em: 30/06/2020

Aprovado em: 05/08/2020

Universidade do Estado de Santa Catarina - UDESC Programa de Pós-Graduação em Teatro - PPGT Centro de Arte - CEART Urdimento - Revista de Estudos em Artes Cênicas urdimento.ceart@udesc.br 